\title{
PENTINGNYA KEPEMIMPINAN DAN KERJASAMA TIM DALAM IMPLEMENTASI MANAJEMEN MUTU TERPADU
}

\author{
Salma Nur Azizah Rahmawati \\ Achmad Supriyanto \\ Fakultas IImu Pendidikan, Universitas Negeri Malang \\ Email: salmaabcdef282@gmail.com
}

\begin{abstract}
The relationship between leadership and member cooperation within an organization and the implementation of integrated quality management is a significant relationship. Leadership plays an important role in an organization's success. Leadership is based on the nature of a person who is able to influence others to achieve common goals. In addition, teamwork also affects the success of the organization. The purpose of the research is to know the importance of leadership and teamwork in improve the quality of education in Indonesia. The method used by researchers is the study literature of various journals. The results of the research are in the form of facts about the importance of leadership and teamwork in succeeding the implementation of total quality management.
\end{abstract}

Keywords: leadership, teamwork, total quality management

\begin{abstract}
Abstrak: Hubungan antara kepemimpinan dan kerjasama anggota dalam sebuah organisasi dengan implementasi manajemen mutu terpadu adalah hubungan signifikan. Kepemimpinan berperan penting dalam kesuksesan suatu organisasi. Kepemimpinan didasari oleh sifat seseorang yang mampu mempengaruhi orang lain untuk mencapai tujuan bersama. Selain itu, kerjasama tim juga berpengaruh terhadap kesuksesan organisasi. Tujuan penelitian adalah untuk mengetahui pentingnya kepemimpinan dan kerjasama sebuah tim dalam peningkatkan kualitas pendidikan di Indonesia. Metode yang digunakan oleh peneliti adalah study literature dari berbagai jurnal. Hasil penelitian berupa fakta mengenai pentingnya kepemimpinan dan kerjasama tim dalam mensukseskan implementasi total quality management.
\end{abstract}

Kata kunci: kepemimpinan, kerjasama tim, manajemen mutu terpadu

Pendidikan adalah proses dimana potensi individu dikembangkan melalui kebiasaan tertentu untuk kebaikan inividu itu sendiri. Sekolah merupakan sebah tempat/lembaga yang berfungsi untuk meelaksanakan pendidikan. Sekolah berperan dalam peningkatan mutu dan kualitas pendidikan. Pendidikan adalah faktor utama peningkatan kualitas manusia di negara. Sumber daya manusia yang cukup adalah faktor keberhasilan pembangunan di suatu negara (Saputro, 2016). Dapat disimpulkan pemberdayaan sumber daya manusia yang baik dapat meningkatkan mutu pendidikan di suatu negara. Kepemimpinan merupakan proses menggerakkan, memengaruhi, memotivasi, serta mengarahkan anggota di lembaga untuk mencapai tujuan bersama. Dalam mewujudkan tujuan tersebut seorang pemimpin pendidikan harus mampu bekerjasama dengan bawahannya. Kepemimpinan adalah proses seseorang mempengaruhi orang lain dalam rangka pencapaian tujuan dari suatu organisasi. Jiwa kepemimpinan tentu menjadi faktor penting dalam kehidupan bermasyarakat karena dengan begitu manusia dapat berkembang dengan mengelola dirinya. Terutama dalam suatu organisasi, kepemimpinan dapat dijadikan sebagai indikator keberhasilan suatu organisasi tersebut.

Seiring perkembangan zaman membuat dunia pendidikan semakin penuh dengan perubahan, di Indonesia sendiri 
juga terjadi perubahan zaman yang ditandai dengan penggunaan media, seperti penggunaan komputer serta internet.

Manajemen Mutu Terpadu adalah pengelolaan yang mengutamakan kualitas (Rohman, 2017). Manajemen mutu terpadu merupakan proses mengelola suatu pendidikan dengan perbaikan terusmenerus yang mengutamakan mutu pendidikan serta untuk meningkatkan daya saing demi kepuasan pelanggan pendidikan.

Menurut Candrama (2011) Total Quality Management merupakan strategi mengelola pendidikan dengan menggabungkan semua substansi manajemen pendidikan dan melibatkan seluruh anggotanya untuk bekerjasama mencapai sekolah yang lebih berkualitas. Dalam TQM, kepala sekolah harus memiliki sikap yang mampu mendorong, memotivasi, jujur, berintegritas, kreatif, percaya diri, inisiatif, fleksibel, memiliki kemampuan kognitif, berpengetahuan bisnis dan kharismatik (Bukhari, 2016). Manajemen mutu terpadu adalah seluruh kegiatan dari 6 substansi manajamen pendidikan. Tanggung jawab dalam peningkatan mutu terdapat pada semua tahap manajamen, yang harus dikelola dengan manajemen inti. Dalam penerapan manajamen mutu, pemimpin harus melibatkan semua anggotanya untuk bekerjasama dengan baik (Bakar, 2015). Tujuan penelitan ini adalah untuk mengetahui pentingnya kepemimpinan kepala sekolah dan kerja tim dalam keberhasilan pelaksanaan manajemen mutu terpadu.

\section{METODE}

Penelitian ini adalah penelitian menggunakan Systematic Literature Reviews (SLR), yakni sebuah sintesis dari studi literatur yang bersifat sitematik, jelas, menyeluruh, dengan mengidentifikasi, menganalisis, mengevaluasi melalui pengumpulan data-data yang sudah ada dengan metode pencarian yang eksplisit dan melibatkan proses telaah kritis dalam pemilihan studi. Pada artikel ini, penelitian menggunakan metode studi literatur dengan mengumpulkan bahan materi yang bersumber dari berbagai macam jurnal. Artikel disusun dengan materi-materi dari segala sumber dengan dimulai dari materi dasar sampai materi utama dalam manajemen mutu terpadu.

Ada beberapa metode yang dapat dilakukan untuk melakukan Studi Literatur, seperti mengupas (criticize), membandingkan (compare), meringkas (summarize), dan mengumpulkan (synthesize) suatu literatur.

\section{HASIL}

Kualitas pendidikan berhubungan dengan usaha kepala sekolah sebagai pemimpindan kinerja stakeholder sebagai sebuah teamwork yang dapat mensukseskan penerapan manajemen mutu terpadu. Untuk menjadi pemimpin yang haruslah sering terlibat dalam kerjasama (teamwork). Dengan mengikuti berbagai kerja sama maka pemimpin dapat mengembangkan dirinya untuk menghadapi masalah-masalah saat menjadi seorang pemimpin di sebuah organisasi. Dalam sekolah yang berkualitas menunjukkan pentingnya kepemimpinan dan kinerja lembaga atau kerja sama dalam sebuah tim. Jika manajemen mutu terpadu dimaksimalkan maka mutu sekolah akan meningkat sesuai dengan keinginan.

Manfaat penerapan manajemen mutu terpadu untuk meperbaiki, memberikan pelayanan, mengurangi biaya operasional, dan memuaskan pelanggan pendidikan. Dalam peningkatan mutu pendidikan manajemen SDM juga berpengaruh, hal ini karena dalam sebuah organisasi dukungan dari sumber daya manusia dan pengelolaan yang baik dapat membuat organisasi lebih maju dan berkembang.

Kepala sekolah merupakan seorang pemimpin dalam pendidikan berperan penting terhadap implementasi TQM kepala sekolah berperan menjadi penasehat sekaligus motor penggerak dalam upaya perbaikan. Dalam implementasi TQM kepala sekolah harus melibatkan karyawan mulai dari perencanaan hingga pengambilan keputusan untuk mendorong etos kerja dan prestasi karyawan. Selain itu, kerjasama tim juga berpengaruh terhadap 
kesuksesan implementasi TQM, karena dianggap bahwa pemikiran suatu kelompok lebih baik daripada pemikiran satu orang.

Dalam menjamin mutu pendidikan haruslah memanajemen anggotanya agar perkembangan sekolah semakin maju sehingga sekolah dapat berkembang. Pemberdayaan sumber daya manusia adalah suatu hal penting untuk dilakukan dalam pencapaian tujuan lembaga, karena semakin kuat pemikiran sumber daya manusia maka suatu organisasi semakin maju. Mutu pendidikan dapat dinilai oleh konsumen pendidikan yang salah satunya dilihat dari sumber daya manusianya, oleh sebab itu dalam TQM peran manajemen sumber daya sangat diperhatikan karena di lembaga pendidikan memberikan/menjual jasa. Sehingga dapat disimpulkan bahwa peran SDM dan adanya kerja sama yang baik di dalam organisasi akan mewujudkan pengelolaan mutu yang baik.

\section{PEMBAHASAN}

Pendidikan adalah usaha dalam membentuk karakter individu dan sesuai dengan nilai yang berlaku. Oleh karena itu, lingkungan baik akan menunang pendidikan. Dalam pendidikan terdapat lingkungan pendidikan yang juga merupakan hal yang penting dalam dunia pendidikan untuk membentuk peserta didik menjalani pendidikan.

Sekolah sebagai lembaga yang berfungsi untuk melaksanakan pendidikan sesuai dengan kebijakan pemerintah yang telak ditetapkan (Herawan, 2016). Sekolah bertujuan untuk mencerdaskan anak bangsa, oleh karena itu sekolah tidak seenaknya berjalan. Sekolah harus memperhatikan aspek-aspek kualitas.

\section{Pentingnya Kepemimpinan Kepala Sekolah}

Kepemimpinan adalah proses seseoang untuk mempengaruhi orang lain dalam upaya pencapaian tujuan bersama (Nasution, 2015). Soekarno dalam Muflihin menyebutkan bahwa kepemimpinan adalah seluruh aktivitas dalam mempengaruhi serta menggerakkan indvidu lain dalam upaya mencapai tujuan bersama. Dalam mencapai tujuan diperlukan kerjasama tim yang baik antara pemimpin atau atasan dan bawahannya.

Kepemimpinan adalah proses menggerakkan yang berhubungan dengan tugas anggota organisasi juga sarana pencapaian tujuan. Kepemimpinan dapat dikatakan sangat penting jika pemimpin mengelola organisasi dengan tepat. Maka dari itu pemimpin harus mendorong sifat positif dan menghilangkan sifat yang negatif, mencari pemecahan masalah, mempelajari perubahan di sekitar, dan membuat strategi yang tepat untuk mencapai tujuan.

Kepala sekolah merupakan pemimpin pendidikan yang berpengaruh terhadap peningkatan mutu. Menurut Ekosiswoyo, (2007) kepala sekolah merupakan panutan dalam menentukan kebijakan, untuk mewujudkan tujuan-tujuan pendidikan. Kepala sekolah memegang kunci atau peran yang penting. Peran dan fungsi kepala sekolah sebagai seorang pemimpin disebutkan dalam (Septiana \& Ivada, 2013) yaitu sebagai pendidik, pengelola, administrator, supervisor, pemimpin, inovasi, dan motivator.

Peran kepala sekolah tersebut betujuan untuk perbaikan dan peningkatan mutu. Kepemimpinan kepala sekolah merupakan proses dalam mempengaruhi, memotivasi guru bekerja secara maksimal. Dengan adanya motivasi kerja dapat mempengaruhi kinerja guru menjadi lebih baik.

Yukl dalam (Susanty dkk., 2011) Kepemimpinan transformasional merupakan kemampuan pemimpin dalam mempengaruhi anggotanya sehingga anggotanya dapat merasakan kepercayaan, bangga, loyal dan rasa hormat terhadap pemimpin, serta dapat memotivasi anggotanya untuk melakukan yang lebih baik. Berdasarkan penelitian Susanty dkk (2011) pemimpin yang transformasional dapat mempengaruhi penerapan TQM dan komitmen anggota organisasi. Maka kepala sekolah transformasional lebih berpengaruh terhadap peningkatan mutu pendidikan.

Pemimpin dalam sekolah harus memiliki dua keterampilan yaitu keterampilan memimpin dan keterampilan manajerial. Sikap pemimpin dalam pelaksanaan keterampilan ini sangat 
berpengaruh terhadap (Syamsul, 2017). Selain itu kepala sekolah harus menyesuaikan 4 prinsip manajemen mutu terpadu, yaitu: (1) Kepuasan masyarakat;, (2) peduli terhadap setiap orang; (3) manajemen berdasarkan fakta;

Perbaikan terus menerus. Perilaku kepemimpinan kepala sekolah.

\section{Pentingnya Kerjasama Tim}

Tim adalah salah satu faktor keberhasilan organisasi, maksudnya semua anggota organisasi dan dan lembaga pendidikan berkerjasama untuk suatu tujuan yang telah ditetapkan yang memfokuskan terhadap kepuasan pelanggan (Kav, 2018). Dalam teori keseimbangan dielaskan bahwa suatu kelompok akan berhasil jika memiliki anggota yang baik dan manaemen yang baik pula, jadi kerjasama tim dan kepemimpinan saling berhubungan. Newcomb dalam Hastuti \& Wijayanti, (2009) Kerjasama tim (teamwork) dalam sekolah adalah seluruh warga lembaga pendidikan harus ikut serta dalam kegiatan-kegiatan lembaga pendidikan sehingga terbentuknya kera tim. Mutu sebuah pendidikan tidak hanya dilihat dari kualitas lulusannya saja, namun dapat dilihat juga dari pemenuhan kebutuhan sekolah yang sesuai dengan standar mutu dalam Undang-undang yang berlaku

Menurut Yusmina \& Ar, (2017) kinerja anggota organisasi yang berperan dalam mewujudkan tujuan pendidikan sangat penting untuk. Efektivitas sumber daya manusia tidak jauh dari dari pengaruh gaya kepemimpinan seorang kepala sekolah.

Menurut Gunawan dalam (Safii, 2016) gaya kepemimpinan merupakan suatu cara atau langkah untuk mempengaruhi seluruh anggota melaksanakan kehendak. Dalam persaingan saat ini organisasi akan sulit bertahan tanpa kemampuan menghadapi perubahan (Umam, 2018). Dalam meningkatkan mutu pendidikan sekolah di haruskan untuk berubah, memperbaiki, dan mengelola kebijakan dengan efektif dan efisien. Kerja tim sangat penting dalam hal ini, dengan bantuan antar individu maka peningkatan mutu akan lebih mudah dilakukan.
Faktor-faktor pendukung adanya perubahan organisasional diantaranya adalah dengan dukungan yang efektif, efektivitas organisasi, anggota khusus untuk melakukan perubahan terusmenerus, komunikasi yang baik, perencanaan, dan pendekatan yang terorganisir. Peningkatan kualitas pembelajaran dapat ditingkatkan apabila implementasi TQM dilakukan secara serius, didukung oleh stakeholders, berjalan secara sistemik dan sistematis, terus-menerus dan berkesinambungan (Supriyanto, 2015).

Menurut Bukhari kerjasama dalam dalam pencapaian mutu harus dkembangkan untuk mencapai hasil yang maksimal. Manajemen sumber daya manusia merupakan kunci tumbuhnya suatu organisasi. Oleh sebab itu kerjasama tim adalah faktor penting dalam implementasi TQM. Dalam meningkatkan kualitas sumber daya manusia dapat dilakukan dengan upaya seperti, Workshop, seminar, pelatihan, MGMP, dan KKG. Melalui kegiatan-kegiatan tersebut maka akan terbentuk kerjasama tim yang baik.

Tim adalah kelompok orang-orang dengan tujuan yang sama. Pentingnya kerjasama tim didasari oleh beberapa faktor diataranya, pemikiran dua orang atau lebih jauh lebih baik dibandingkan satu orang, sesuatu yang dihasilkan sebuah tim lebih baik dibandingkan yang dihasilkan individu, anggota organisasi dapat mengenal satu sama lain dengan baik karena adanya kerjasama tim, dan komunikasi menejadi lebih baik dengan kerjasama tim.

Pengelolaan kinerja dapat dikatakan berhasil jika adanya kerjasama yang baik dalam (Setiyanti, 2012). Dengan adanya kerjasama tim yang baik organisasi akan dapat menyelesaikan permasalahan dengan cepat dan tepat. Dalam sebuah tim, individu-individu cenderung lebih nyaman untuk mengungkapkan sebuah masalah maupun pendapat sehingga dapat segera memperoleh bantuan dari anggota yang lain.

Implementasi Manajemen Mutu Terpadu 
Menurut (Khikmah \& Yuliejantiningsih, 2019) saat ini semua lembaga pendidikan berorientasi pada mutu. Hal tersebut menjadi tantangan besar bagi lembaga pendidikan untuk berkembang menjadi lebih baik.

\section{Konsep Manajemen Mutu Terpadu/Total Quality Management}

Mutu adalah kegiatan dalam angka panjang yang harus melibatkaan semua pihak terkait (Syukron, 2016). Mutu merupakan proses yang tertata untuk perbaikan. Mutu merupakan suatu hal yang didasarkan oleh logika dan akal yang sehat (Idi dkk., 2015). MMT/TQM menurut Sallis dalam (Meilanie \& Aminah, 2009) adalah sebuah pemikiran mengenai perbaikan bertahap yang dapat memberikan keuntungan pada sebuah lembaga. Menurut Aziz (2015) manajemen mutu terpadu adalah sebuah pendekatan untuk suatu organisasi yang fokus terhadap kualitas berdasarkan pada kerjasama semua anggota organisasi untuk memsukseskan program jangka panjang

TQM menekankan pada kualitas dan pengembangan berdasarkan kepentingan pelanggan (Husna, 2014). Manajemen mutu terpadu adalah proses mengelola pendidikan yang fokus terhadap perbaikan untuk meningkatkan dan mengembangkan kualitas suatu produk/jasa.

Manajemen mutu terpadu dalam pendidikan adalah proses mengelola pendidikan dalam upaya perbaikan dan pengembangan dan menuntut dukungan serta keinginan pemerintah, warga sekolah dan (Hendartho, 2018). Menurut (Indana, 2017) manajemen mutu terpadu di sekolah merupakan sebuah pemberian/pelayanan jasa maupun produk.

\section{Prinsip Manajemen Mutu Terpadu}

Penerapan manajemen mutu terpadu harus dilaksanakan dengan berpedoman terhadap prinsip-prinsip TQM (Rouf, 2015): (1) Fokus terhadap konsumen, sekolah harus memahami semua produk pendidikan memiliki pengguna; Kerjasama, setiap anggota organisasi harus terlibat dalam upaya paencapaian mutu; (3) Mengukur pencapaian, sekolah harus mampu mengukur seberapa jauh mutu pendidikan tercapai; (4) Pendidikan merupakan sistem, sekolah harus dapat memahami bahwa pendidikan adalah sebuah sumber yang memiliki komponenkomponen untuk dikelola; (5) Perbaikan terus-menerus. Dalam pencapaian mutu maka diharuskan untuk melakukan perbaikan secara terus menerusuntuk hasil yang maksimal.

Sedangkan mrnurut Deming ada 14 prinsip manaemen (Sriwidadi, 2001): (1) Menciptakan fungsi perbaikan produk dan jasa secara konstan; (2) Menolak kebiasaan salah, rusak, dan ditunda; (3) Menghilangkan inspekksi massal; (4) Meminimalisisr biaya; (5) Melakukan perbaikan dengan konsisten dan berlaku selamanya; (6) Pelatihan karyawan; (7) Mementingkan manajemen dan supervisi dalam kepemimpinan; (8) Tidak membuat karyawan ketakutan; (9) Mengembangkan kerjasama dan menyingkirkan penghalang; (10) Menghilangkan kegiatan yang mendesak; (11) Menjalankan kepemimpinan yang baik dengan melakukan perbaikan mulai dari awal proses kerjasama; (12) Menghilangkan sistem kerja yang salah; (13) Mengembangkan pendidikan; (14) Mengkoordinasi karyawan untuk menerapkan prinsip.

\section{Implementasi Manajemen Mutu Terpadu}

Total Quality Management adalah proses keseluruhan manajemen yang menitikberatkan kepuasan pelanggan untuk meningkatkan mutu pendidikan dengan pengurangan biaya (Dodi, 2017). Implementasi TQM merupakan proses menerapkan seluruh manajemen yang melibatkan seluruh anggota atau komponen dalam suatu organisasi untuk melakukan perbaikan secara terusmenerus dengan fokus terhadap (Ismail, 2018). Menurut Sallis dalam (Arifin, 2018), TQM sangat mudah untuk dilakukan atau diterapkan dalam sebuah lembaga baik lembaga yang besar maupun lembaga kecil. Implementasi TQM adalah penerapan seluruh sistem manajemen yang fokus terhadap kepuasan pelanggan dan melakukan perbaikan untuk meningkatkan mutu pendidikan di suatu lembaga. 
Manajemen mutu terpadu dapat membentuk masyarakat yang dengan mudah merespon perubahan di era sekarang (Khadijah, 2015). Dalam pelaksanaan manajemen mutu terpadu di bidang pendidikan TQM memiliki ati penting dalam memberikan kepuasan (Prestiadi dkk., 2015). Menurut Hensler dan Brunell dalam (Asikin, 2017) terdapat empat prinsip TQM, yaitu: (1) Kepuasan pelanggan; (2) peduli pada setiap orang; (3) mengelola berdasarkan fakta; (4) perbaikan terus menerus.

Lembaga pendidikan harus sadar untuk mempelajari perkembangan zaman yang sangat pesat dserta mempelajari perbaikan dan peningkatan mutu secara berkesinambungan untuk mencapai kepuasan dari pelanggan (Suhermanto \& Anshari, 2018). Menurut Rahmah (2018), TQM pendidikan memiliki tujuan utama yaitu meningkatkan mutu pendidikan secara terus menerus dan berkelanjutan, serta terpadu sehingga dapat memuaskan pelanggan pendidikan. Pada penelitian Hartantyo \& Hendayani (2015) ditemukan fakta bahwa total quality management berpengaruh terhadap kepuasan pelanggan, hasil penelitian tersebut menunjukkan adanya hubungan yang signifikan antara TQM dan kepuasan peanggan. Menurut Rago dalam (Sukwadi, 2007), terdapat hal-hal yang mempengaruhi implementasi manajemen mutu terpadu yang meliputi tujuan, koordinasi, komunikasi, dan pencapaian. Sedangkan 10 faktor sukses untuk implementasi TQM yaitu struktur tim kerja, kepuasan konsumen, manajemen kualitas, top manajemen, keterlibatan pegawai, fokus pada konsumen, komitmen pekerja, pendidikan dan pelatihan, kualitas perencanaan, dan kualitas data (Fahmi, 2019). Kepemimpinan yang efektif, partisipasi seluruh bagian perusahaan, dan perbaikan yang kontinu merupakan indikator suksesnya peran TQM dalam kepemimpinan kualitas.

\section{KESIMPULAN}

Berdasarkan pembahasan pada artikel ini dapat disimpulkan bahwa manajemen mutu terpadu merupakan rangkaian proses keselruhan manajemen pendidikan yang menitkberatkan terhadap perbaikan untuk meningkatkan dan mengembangkan kualitas suatu produk/jasa.Kepala sekolah sangat berpengaruh, dimana dalam implementasi TQM kepala sekolah berperan menjadi penasehat sekaligus motor penggerak dalam upaya perbaikan. Dalam penerapan manajemen mutu terpadu pemimpin harus memiliki kemampuan kepemimpinan dan kemampuan manajerial. Hubungan kepemimpinan dengan TQM adalah cara untuk memotivasi individu-individu untuk meningkatkan mutu pendidikan dan tercapainya tujuan organisasi. Dalam pencapaian suatu tujuan organisasi dibutuhkan kerjasama tim yang baik.

Tim adalah sekumpulan individu yang mempunyai tujuan sama. Pentingnya sebuah tim didasari oleh faktor-faktor berikut: (1) Pemikiran dua orang atau lebih,lebih baik dibandingkan satu orang, (2) hasil tim jauh lebih baik, (3) adanya interaksi yang baik antar anggota, (4) komunikasi yang baik. Faktor utama dalam peningkatan kualitas dalam pendidikan adalah dengan melakukan pemberdayaan sumber daya manusia. Kualitas pendidikan tidak hanya dilihat dari hasil namun dapat dilihat dari cara sekolah memenuhi kebutuhan sekolahnya yang sesuai dengan standar mutu pendidikan.

Implementasi TQM adalah penerapan seluruh sistem manajemen yang fokus terhadap kepuasan pelanggan. Dalam penerapan TQM terdapat prinsip-prinsip yang dilaksanakan untuk hasil yang maksimal. Sehingga kepala sekolah menjadi penggerak dan motivator bagi anggotanya untuk berubah menjadi lebih baik untuk mencapai tujuan yang dharapkan. Karena dalam sebuah pencapaian suatu tujuan pasti didasari oleh kerjasama tim yang baik

Kesimpulan yang dapat diambil adalah. kepala sekolah berperan menjadi pemimpin yamng mampu memotivasi, menggerakkan anggotanya dan mengelola organisasi dengan baik, dapat dikatakan kepala sekolah juga harus menciptakan lingkungan kerja yang efektif dan efisien. Anggota oorganisasi harus mampu bekerjasama dengan baik untuk terciptanya suatu tujuan. Dengan 
tercapainya suatu tujuan maka kinerja dapat dikatakan berhasil.

\section{SARAN}

Kepala sekolah sebagai seorang pemimpin hendaklah menjadi contoh bagi anggotanya. Kepala sekolah lebih dulu memperbaiki kinerjanya sebelum memperbaiki kinerja anggotanya. Dalam pencapaian tujuan kerjasama tim yang baik perlu dierhatikan. Dalam menjamin mutu pendidikan haruslah terlebih dahulu memanajemen sumber daya manusia agar perkembangan organisasi semakin maju sehingga mutu pendidikan akan meningkat. Mutu pendidikan akan dinilai oleh pelanggan yang dilihat dari salah satunya segi manajemen sumber daya manusia,oleh karena itu dalam TQM peran MSDM sangat diperlukan dalam meningkatkan mutu karena pada lembaga pendidikan itu menjual jasa.

\section{DAFTAR RUJUKAN}

Arifin, Z. (2018). Implementasi Total Quality Management (TQM). 12.

Asikin, I. (2017). Implementasi Total Quality Management (TQM) di Pendidikan Tinggi. 6(2), 17.

Aziz, A. (2015). Peningkatan Mutu Pendidikan. 10(2), 14.

Bakar, H. A. (2015). Dukungan Kepemimpinan Mutu Perguruan Tinggi Dalam Penerapan Manajemen Mutu Terpadu (MMT): Studi Kasus pada STAIN Watampone. 16.

Bukhari, A. (t.t.). Kepemimpinan Transformasional Pendidikan Berbasis Total Quality Manajement (TQM). 14.

Candrama, D. (2011). Pengaruh Total Quality Management (TQM), Gaya Kepemimpinan,. 110.

Dodi, L. (2017). Metamorfosis Gerakan Sosial Keagamaan: Antara Polemik, Desiminasi, Ortodoksi, dan Penerimaan terhadap Ideologi Lembaga Dakwah Islam Indonesia (LDII). Al-Tahrir: Jurnal Pemikiran Islam, $17(1)$, 227. https://doi.org/10.21154/altahrir.v17 i1.880

Ekosiswoyo, R. (2007). Kepemimpinan Kepala Sekolah Yang Efektif Kunci Pencapaian Kualitas Pendidikan. 7.

Fahmi, A. A. (2019). Kajian Faktor Kesuksesan Implementasi Total Quality Management di Perguruan Tinggi. 6.

Hartantyo, H. T., \& Hendayani, R. (2015). Analisis Implementasi Total Quality Management (TQM) Dan Pengaruhnya Terhadap Kepuasan Konsumen dan Service Quality. 4(2), 15.

Hastuti, S., \& Wijayanti, L. (2009). Kinerja Manajerial: Hasil Kerjasama Tim Dan Perbaikan Berkesinambungan. $1,9$.

Hendartho, D. (2018). Analisis Implementasi Sistem Manajemen Mutu ISO 9001:2008 Pada Sekolah Tinggi Ilmu Administrasi Mandala Indonesia. Transparansi Jurnal IImiah IImu Administrasi, 6(2), 124138.

https://doi.org/10.31334/trans.v6i2. 37

Herawan, E. (2016). Kepemimpinan Mutu Kepala Sekolah Dalam Peningkatan Mutu Pendidikan. Pedagogia Jurnal IImu Pendidikan, 12(2),

51. https://doi.org/10.17509/pedagogia. v12i2.3329

Husna, A. (2014). Penerapan Manajemen Mutu Terpadu Dan Dampaknya Di Sd Budi Mulia Dua Sedayu Bantul. Jurnal Penelitian IImu Pendidikan, 7, 12.

Idi, A., Suharto, T., Mulkhan, M., \& Arcaro, S. (2015). Pengembangan Madrasah Bermutu. 15.

Indana, N. (2017). Implementasi Total Quality Management (Tqm) Dalam Meningkatkan Mutu Pendidikan (Studi Kasus di MTs Salafiyah Syafi'iyah Tebuireng). 25.

Ismail, F. (2018). Implementasi Total Quality Management (TQM) di 
Lembaga Pendidikan. Jurnal IImiah lqra', 10(2). https://doi.org/10.30984/jii.v10i2.59 1

Kav, J. U. S. (2018). Subaidi ${ }^{1}$ dan Samidi Khalim². 04, 10.

Khadijah, I. (2015). Manajemen Mutu Terpadu (TQM) Pada Lembaga Pendidikan Islam. 18.

Khikmah, N., \& Yuliejantiningsih, Y. (2019). Implementasi Total Quality Management Dalam Peningkatan Mutu Sekolah Di SMA Negeri 1 Slawi Kabupaten Tegal. Jurnal Manajemen Pendidikan, 8, 21.

Meilanie, R. S. M., \& Aminah, N. (2009). Implementasi Manajemen Mutu Terpadu Dalam Meningkatkan Mutu Pendidikan. Perspektif IImu Pendidikan, 20(XI), 59-74. https://doi.org/10.21009/PIP.202.7

Muflihin, M. H. (1970). Kepemimpinan Pendidikan: Tinjauan terhadap Teori Sifat dan Tingkah-laku. INSANIA: Jurnal Pemikiran Alternatif Kependidikan, 13(1), 6786.

https://doi.org/10.24090/insania.v13 i1.286

Nasution, W. N. (2015). Kepemimpinan Pendidikan Di Sekolah. 22(1), 21.

Prestiadi, D., Hardyanto, W., \& Pramono, S. E. (2015). Implementasi Total Quality Management (TQM) Dalam Mencapai Kepuasan Siswa. 9.

Rahmah, U. (2018). Implementasi Total Quality Management (TQM) di SD Al-Hikmah Surabaya. 3, 21.

Rohman, N. (2017). Peran Kepala Sekolah Dalam Peningkatan Mutu Pendidikan Perspektif Manajemen Mutu Terpadu Studi Kasus Di Sdut Bumi Kartini Jepara. Tarbawi : Jurnal Pendidikan Islam, 14(2). https://doi.org/10.34001/tarbawi.v14 i2.625

Rouf, M. (2015). Implementasi Tqm (Total Quality Management) Pada Lembaga Pendidikan. 18.
Safii, M. (2016). Peran Kepala Sekolah Sebagai Supervisor Dalam Terwujudnya Perpustakaan Sekolah Sebagai Pusat Sumber Belajar. 11.

Saputro, A. D. (2016). Implementasi Manajemen Mutu Terpadu Di Sekolah/Madrasah. 17.

Septiana, R. \& Ivada, E. (2013). Pengaruh Kepemimpinan Kepala Sekolah Dan Motivasi Kerja Terhadap Kinerja Guru Smp Negeri Wonosari. 2(1), 12.

Setiyanti, S. W. (2012). Jurnal Stie Semarang, Vol 4, No 3, Edisi Oktober 2012 (ISSN: 2252-7826). $4(3), 7$.

Sriwidadi, T. (2001). Manajemen Mutu Terpadu. 2(2), 9.

Suhermanto, S. \& Anshari, A. (2018). Implementasi Tqm Terhadap Mutu Institusi Dalam Lembaga Pendidikan. Al-Tanzim: Jurnal Manajemen Pendidikan Islam, 2(1), 107-113.

https://doi.org/10.33650/altanzim.v2i1.259

Sukwadi, R. (2007). Pengembangan Model Konseptual: Peran TQM Dalam Kepemimpinan Berkualitas Untuk Meningkatkan Kinerja Perusahaan. 8(1), 16.

Supriyanto, A. (2015). Implementasi Total Quality Management Dalam Sistem Manajemen Mutu Pembelajaran Di Institusi Pendidikan. Jurnal Cakrawala Pendidikan, 1(1). https://doi.org/10.21831/cp.v1i1.418 8

Susanty, A., Puspitasari, D., \& Aisyah, S. (2011). Analisis Hubungan Kepemimpinan Transformasional Terhadap TQM, Komitmen Organisasi Dan Kinerja Karyawan (Studi Kasus: PT Telekomunikasi Indonesia Divre IV Jateng \& DIY). $1,10$.

Syamsul, H. (2017). Penerapan Kepemimpinan Kepala Sekolah Dalam Meningkatkan Kinerja Guru 
Pada Jenjang Sekolah Menengah Pertama (SMP). Idaarah: Jurnal Manajemen Pendidikan, 1(2). https://doi.org/10.24252/idaarah.v1i 2.4271

Syukron, B. (2016). Implementasi Manajemen Mutu Terpadu: Studi Transformasi Pada Perguruan Tinggi. 5(1), 13.

Umam, M. K. (2018). Komite Madrasah Dalam Konteks Manajemen Mutu Terpadu Pendidikan Islam. 18.

Yusmina, E., \& Ar, M. (2014). Implementasi Manajemen Mutu Terpadu Dalam Peningkatan Kinerja Sekolah Pada SMK Negeri 1 Banda Aceh. 11. 